\title{
Untreated Childhood Fibrillary Astrocytoma
}

National Cancer Institute

\section{Source}

National Cancer Institute. Untreated Childhood Fibrillary Astrocytoma. NCI Thesaurus.

Code C115934.

A finding of fibrillary astrocytoma in childhood that has not been treated. 